\title{
THE EFFECT OF PLANT HORMONE INDOLE ACETIC ACID (IAA) ON HEMATOLOGICAL \& BIOCHEMICAL PARAMETERS IN MICE
}

\author{
M. H. MORSHED ${ }^{1}$, M. SHAMIM HOSSAIN², M. ANWAR HABIB ${ }^{3}$, MM MOINUDDIN AHMED $^{4}$, M. IBRAHIM ${ }^{5}$, M. UMAR ALI $^{6}$ \\ M. AZIZUL ISLAM ${ }^{7}$ \\ Department of Chemistry, Khulna University of Engineering and Technology, Khulna-9203 ${ }^{1}$, Microbiology and \\ Biotechnology Laboratory, Department of Pharmacy, Rajshahi University, Rajshahi-62052; Department of \\ Pharmacology and Therapeutics, Rajshahi Medical College, Rajshahi ${ }^{3}$, Department of Physiology, Khulna Medical \\ College, Khulna ${ }^{4}$, BCSIR Laboratories, Binodpur Bazar, Rajshahi- $6206^{5}$, Department of Chemistry, Rajshahi \\ University; Rajshahi-6205
}

\begin{abstract}
The subacute toxicity of plant hormone indoleacetic acid (IAA) was studied on Swiss albino mice. The studies include the gross general observation such as changes in body weight, hematological profiles [total count of red blood cells (RBC) and white blood cells (WBC), differential count of WBC, platelet count, hemoglobin $(\mathrm{Hb}) \%$ ], biochemical parameters of blood [serum glutamate oxaloacetate transaminase (SGOT), serum glutamate pyruvate transaminase (SGPT), serum alkaline phospatase(SALP), creatinine] and histopathology of the liver, kidney, lung, spleen, heart and brain of both control and experimental

day $^{-1}$ for consecutive 14 days, showed no significant change of hematological and biochemical parameters. No abnormalities were also found in the histopathology of the liver, kidney, lung, spleen, heart and brain in the experimental group of animals following same dose when compared with control group. This preliminary toxicological study suggests that the plant hormone indoleacetic acid (IAA) may be used safely for agricultural purposes and as an external preservative.
\end{abstract}

(Bangladesh J Physiol Pharmacol 2006; 21(1/2) : 5-8)

\section{INTRODUCTION}

The plant hormones (auxin) regulate the amount, type and direction of plant growth. They are found in all members of the plant kingdom. Auxin affects numerous plant processes, e.g., cell division and elongation, autumnal loss of leaves and the formation of buds, roots, flowers and fruits ${ }^{1}$. They are widely used commercially to produce more vigorous growth, to promote flowering and fruiting and also root formation in plants not easily propagated by stem cuttings, to retard fruit drop and to produce seedless varieties (e.g., of tomatoes) by parthenogenetic fruiting ${ }^{1,2}$. Indoleacetic acid (IAA) is the principal natural auxin. In the previous studies, IAA was found to have excellent role as plant growth promoters ${ }^{2}$. IAA was also reported to produce larger fruits ${ }^{2}$. Anticancer property has been reported for the compound indoleacetic acid (IAA) and its different derivatives ${ }^{3,4,5}$. Diverse mechanisms have been reported associated with its activities $^{4,6,7}$. IAA has also been reported to have antifungal property against some plant fungi8,9. Antibacterial characteristic was also reported for the compound indoleacetic acid ${ }^{10}$. The application of indoleacetic acid (IAA) as an external preservative has also been reported for different cultivars of mango ${ }^{11,12}$.

Address of Correspondence : Dr. Md. Anwar Habib, Department of Pharmacology and Therapeutics, Rajshahi Medical College, Rajshahi, Bangladesh
So far we know, subacute toxic effects of indoleacetic acid (IAA) have not been investigated that limits its application. So it is thought worthwhile to investigate the different hematological and biochemical profiles with a view to assess its safety profile which may be helpful for its application.

\section{MATERIALS AND METHODS}

For the purpose of study, Swiss albino mice (12 nos, male) of two weeks old, weighing 23-28 g were collected from ICDDRB, Mohakhali, Dhaka. The mice were kept in properly numbered iron cages individually in a clean animal house with an optimal room temperature (25$30^{\circ} \mathrm{C}$ ) and were given standard laboratory diet and allowed to drink water ad libitum ${ }^{13}$. The animals were maintained in this way for 15 days before drug administration and continued up to the end of the experiment. The weight of the individual mice was taken and were grouped into two. The group B (6 mice, average weight $25.17 \mathrm{~g}$ ) was used for experiment while the group A (6 mice, average weight $24.72 \mathrm{~g}$ ) was used as control.

The plant hormone indoleacetic acid (IAA) in a pure grade was made of Fluka company, Germany, was collected and maintained at $4^{\circ} \mathrm{C}$. The compound (IAA) was dissolved in distilled water using tween-20 as cosolvent, so that $0.3 \mathrm{ml}$ contained $300 \mu \mathrm{g}$ of the hormone. The mice in group $A$ and $B$ were injected intraperitoneally with vehicle (300 $\mathrm{ml}$ isotonic saline) and compound (IAA) 
$300 \mu$ mice $^{-1}$ day $^{-1}$ respectively for consecutive 14 days. On the $15^{\text {th }}$ day blood was collected from external jugular vein under mild ether anaesthesia for the estimation of hematological and biochemical parameters. Then all the mice were sacrificed and lung, kidney, liver, spleen, heart and brain were removed for histological study. During the whole experimental period their behavior, central nervous system (CNS) excitation, CNS depression, reflexes, muscular weakness, salivation, diarrhea and food intake were observed. Biochemical parameters included SGOT, SGPT, serum alkaline phosphatase (SALP), urea and serum creatinine were determined by using the procedures reported by Reitman and Franket ${ }^{14}$ Fawcett and Scott ${ }^{15}$ and Coulombe and Favreau ${ }^{16}$.

\section{RESULTS}

Table I shows the change in body weights of all the mice (both group $A$ and $B$ ). The mice of group $A$ and $B$ were being treated with vehicle and the compound (IAA) respectively, showed no signs of tremor, convulsions and reflex abnormalities. The body weights of all the mice (both group $A$ and $B$ ) were increased after treatment. Moreover no muscular numbness of the hind and fore legs, salivation or diarrhea was observed. The food intake per day was also found nornial. So from the results it is decided that hormone (IAA) has no effect on normal growth.

Table II shows hematological profiles that were studied on control group of mice and 14 days of treatment. Each time the value of the parameters in each mice was changed slightly. However the parameters remained within the normal range.

Table III shows biochemical parameters on control group and treatment group of mice. However the parameters remained within the normal range. This indicates that the compound (IAA) has no adverse effects on liver and kidney function.

After the $14^{\text {th }}$ day of drug treatment the animals of both control and experimental groups were sacrificed and the organs such as liver, kidney, lung. spleen, heart and brain were isolated and histopathological examinations were done. No abnormality was observed between the control and the drug treated mice when the tissue slides were examined under microscope. This indicates that the compound (IAA) has no effects on cellular structure, i. e., the hormone does not cause degeneration of cells of these organs (Table IV).

Table-I

Effect of Compound (IAA) on body weight of mice

\begin{tabular}{lcccc}
\hline Group & $\begin{array}{c}\text { Dose (i.p.) } \\
\mu \text { mice }^{-1} \text { day } \\
\mathrm{n}=6, \mathrm{M}_{1} \pm \mathrm{SD}_{1}\end{array}$ & $\begin{array}{c}\text { Body weight }(\mathrm{g}) \\
\text { before hormone treatment } \\
\mathrm{n}-6, \mathrm{M}_{2} \pm \mathrm{SD}_{2}\end{array}$ & $\begin{array}{c}\text { Body weight }(\mathrm{g}) \\
\text { after hormone treatment }\end{array}$ & \%change \\
\hline A & $300 \mu \mathrm{l}$ vehicle & $24.72 \pm 1.326$ & $31.00 \pm 1.427$ & $+25.40(\mathrm{~S})$ \\
$\mathrm{B}$ & $300 \mu \mathrm{g}$ IAA & $25.17 \pm 1.763$ & $32.48 \pm 2.463$ & $+29.04(\mathrm{~S})$ \\
\hline
\end{tabular}

$M_{1}$, and $M_{2}=$ Sample mean value, $S D_{1}$ and $S D_{2}=$ Standard deviations, $n=$ Number of mice, $+=$ Increase, $S=$ Significant, $G$ roup $A=$ Control mice, Group $B=$ Experimental mice, $I A A=$ Indoleacetic acid.

Table-II

Hematological profiles (TC of RBC, TC of WBC, DC of WBC, platelet count and $\mathrm{Hb} \%$ ) of group $A$ (control) and group $B$ (experimental) mice $(M \pm S D)$

\begin{tabular}{lcc}
\hline Hematological parameters & $\begin{array}{c}\text { Mice treated with } \\
\text { vehicle Group-A } \\
(\text { control) } \\
14^{\text {th }} \text { day }\end{array}$ & $\begin{array}{c}\text { Mice treated with IAA } \\
\text { Group-B } \\
\text { (experimental) } \\
14^{\text {th }} \text { day }\end{array}$ \\
\hline Total RBC count (million cu. $\mathrm{Mm}^{-1}$ ) & $3.92 \pm 0.264$ & $4.15 \pm 0.187$ \\
Total WBC count (thousand $\boldsymbol{\mu l}^{-1}$ ) & $2.73 \pm 0.258$ & $2.98 \pm 0.147$ \\
Differential count of WBC & & \\
a) Neutrophil & $85.50 \pm 1.871$ & $85.33 \pm 1.862$ \\
b) Lymphocyte & $7 \pm 1.265$ & $9.00 \pm 1.265$ \\
c) Monocyte & $5.33 \pm 0.816$ & $4.50 \pm 0.548$ \\
d) Eosinophil & $.33 \pm 0.516$ & $0.67 \pm 0.516$ \\
Platelet count (cu. mm 1) & $237500.00 \pm 44017.040$ & $248333.30 \pm 41673.330$ \\
Haemoglobin gm (\%) & $10.33 \pm 0.816$ & $10.63 \pm 1.291$ \\
\hline
\end{tabular}


Table III

Effect of IAA on biochemical parameters in mice after intraperitoneal administration of $300 \mathrm{~g} \mathrm{~g} \mathrm{mice}^{-1}$ day $^{-1}$

\begin{tabular}{|c|c|c|c|c|c|c|}
\hline $\begin{array}{l}\text { Biochemical } \\
\text { Parameters } \\
\end{array}$ & $\begin{array}{c}\text { Group } A \\
n=6, M_{1} \pm S D_{1}\end{array}$ & $\begin{array}{c}\text { Group B } \\
\mathrm{n}=6, \mathrm{M}_{2} \pm \mathrm{SD}_{2}\end{array}$ & $\%$ change & $t_{c}$ value & $t_{s}$ value & Remark \\
\hline$\overline{\mathrm{SGPT}\left(U L^{-1}\right)}$ & $27.83 \pm 1.833$ & $19.50 \pm 1.865$ & -29.93 & -16.855 & 2.57 & $M D$ \\
\hline SGOT $\left(U L^{-1}\right)$ & $43.67 \pm 2.161$ & $32.33 \pm 2.162$ & -25.97 & -8.841 & & MD \\
\hline $\operatorname{SALP}\left(U L^{-1}\right)$ & $232.33 \pm 8.941$ & $113.17 \pm 8.73$ & -51.29 & -18.955 & & MD \\
\hline Urea $\left(\mathrm{mmol} \mathrm{L}^{-1}\right)$ & $19.27 \pm 0.532$ & $15.80 \pm 0.467$ & -18.01 & -10.311 & & MD \\
\hline $\begin{array}{l}\text { Serum creatinine } \\
\left(\mathrm{mg} \mathrm{dl}^{-1}\right)\end{array}$ & $0.90 \pm 0.089$ & $1.00 \pm 0.089$ & +11.11 & +2.24 & & NS \\
\hline $\mathrm{ESR}\left(\mathrm{mm}\right.$ in $\left.\mathrm{I}^{\mathrm{st}} \mathrm{hr}\right)$ & $7.17 \pm 1.467$ & $9.00 \pm 0.894$ & +25.52 & +5.967 & & $\mathrm{Ml}$ \\
\hline
\end{tabular}

$M_{1}$ and $M_{2}=$ Sample mean value, $S_{1}$ and $S_{2}=$ Standard deviations, $n=$ Number of mice, $+=$ Increase, $-=$ Decrease, $N S=$ Not Significant, $M D=$ Moderately decreased, $M I=$ Moderately increased, $t_{c}=$ Calculated $t$ value, $t_{s}=t$ value at $5 \%$ level of significance, Group $A=$ Control mice, Group $B=$ Experimental mice, IAA = Indoleacetic acid, SGPT = Serum glutamate pyruvate transaminase, $S G O T$ = Serum glutamate oxaloacetate transaminase, SALP $=$ Serum alkaline phospatase, $E S R=$ Erythrocyte sedimentation rate

Table IV

Histopathological studies after treatment with compound (IAA) at a dose level of 300 $\mu$ mice $^{-1}$ day ${ }^{-1}$ for 14 consecutive days

\begin{tabular}{lccccccc}
\hline Group & Dose (i. p) & \multicolumn{5}{c}{ Histopathological changes observed } \\
\cline { 3 - 7 } & $\mu$ mice $^{-1}$ day $^{-1}$ & Liver & Kidney & Lung & Spleen & Heart & Brain \\
\hline AB & $300 \mu$ vehicle $^{n}$ & NAD & NAD & NAD & NAD & NAD & NAD \\
& $300 \mu$ IAA & NAD & NAD & NAD & NAD & NAD & NAD \\
\hline
\end{tabular}

$\mathrm{NAD}=$ No abnormality detected, Group $\mathrm{A}=$ Control mice, Group $\mathrm{B}=$ Experimental mice,

IAA = Indoleacetic acid

\section{DISCUSSIONS}

As a part of our continuous search for plant hormone indoleacetic acid (IAA) and its significant antimicrobial screening was reported. The present work is the continuation of this antimicrobial screening ${ }^{10}$. The results of our present study demonstrate that the compound possesses no adverse effect on Swiss albino mice at a dose of $300 \mu \mathrm{g} \mathrm{mice}^{-1}$ day $^{-1}$. Thus the findings of this investigation and previous investigation would give valuable support to use this plant hormone safely in agricultural purposes and as an external preservative.

\section{ACKNOWLEDGEMENT}

The authors would like to thank to the Chairman, Department of Pharmacy, Rajshahi University, Rajshahi, Bangladesh and to the Head, Department of Pharmacology and Therapeutics, Rajshahi Medical College, Rajshahi, Bangladesh for supplying the lab facilities for performing this study.

\section{REFERENCES}

1. Audesirk G. and Audesirk T. Biology Life and Earth. MACmillan Publising Company, New York, London. 1986 pp: 494-507.

2. Raven PH, Evert RF, Curtis H. Biology of Plants. $2^{\text {nd }}$ edi., Worth publisher, Inc. New York 10016, 1976 pp: 483-496.
3. Folkes LK, Greco O, Dachs GU, Stratford MR, Wardman P. 5-Fluoroindole-3-acetic acid: A prodrug activated by a peroxidase with potential for use in targeted cancer therapy. Biochem. Pharmacol., 2002; 63: 265-272.

4. Folkes LK, Wardman P. Enhancing the efficacy of photodynamic cancer therapy by radicals from plant auxin (indole-3-acetic acid). Cancer Res., 2003; 63: 776-779.

5. Rossiter S., Folkes LK, Wardman P. Halogenated indole-3acetic acids as oxidatively activated prodrugs with potential for targeted cancer therapy. Bioorg. Med. Chem. Lett., 2002; 12: 2523-2526.

6. Folkes LK, Dennis MF, Stratford MR, Candeias LP, Wardman $P$. Peroxidase-catalyzed effects of indole-3-acetic acid and analogues on lipid membranes, DNA, and mammalian cells in vitro. Biochem. Pharmacol., 1999; 57: 375-382.

7. Greco 0, Folkes LK, Wardman P, Tozer GM, Dachs GU. Development of a novel enzyme/prodrug combination for gene therapy of cancer: horseradish peroxidase/indole3 -acetic acid. Cancer Gene Ther., 7: 2000; 1414-1420.

8. Pal KK, Tilak KV, Saxena AK, Dey R, Singh C. Suppression of maize root diseases caused by Macrophomina phaseolina, Fusarium moniliforme and Fusarium graminearum by plant growth promoting rhizobacteria. Microbiol. Res., 2001; 156: 209-223.

9. Yue Q, Miller CJ, White JF.Jr, Richardson M.D. Isolation and characterization of fungal inhibitors from Epichloe festucae. J. Agric. Food. Chem., 2000; 48: 4687-4692. 
10. Morshed MH, Hossain MS, Ibrahim M, Shafique MZ Helali $\mathrm{MOH}$, Samad A, Islam MS, Islam M.A. Bacteria Killing Kinetics of the Four Plant hormones. Pak J Biol Sci 2005; 8(7): 1025-1029.

11. Morshed MH. Studies on the preservation technology of mango to improve its quality and characteristics M.Phil. Thesis, Department of Chemistry, Rajshahi University, Rajshahi, Bangladesh. 2005; p. 24-34.

12. Kalam A. Reduction of Postharvest losses and Extension of Shelf Life of Mango. Ph. D Thesis, Bangladesh Agricultural University, Bangladesh. 2001. p. 134-137.
13. Hawk PB. Oser I, Summerson WH. Practical physiological chemistry $13^{\text {t" }}$ edition, McGraw Hill Bock Company, USA. 1954.

14. Rethman S. Frankel 1954 A colorimetric method for the determination of serum glutamate- glutamte oxalate and glutamate pyruvate transaminases. Am J. Clin. Path. 1957, $28,56-63$.

15. Fawcell JK, Favreau L. A new simple semi micro method for determination of Urea. J Clin. path. 1960, 13: 156-159.

16. Coulombe JJ, Favreau L. ANew simple semi micro method for determination of Urea J Clin. Chem. 1963, 9: 102-108. 